\title{
Suppression of renal cell carcinoma growth in vivo by forced expression of vascular endothelial growth inhibitor
}

\author{
NING ZHANG $^{1 *}$, PENGJIE WU $^{3 *}$, DUOERKUN SHAYIREMU ${ }^{5}$, LIYANG WU $^{1}$, HUI SHAN $^{1}$,

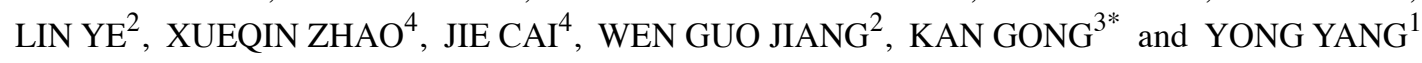 \\ ${ }^{1}$ Department of Urology, Beijing Chaoyang Hospital, Capital Medical University, Beijing 100020, P.R. China; \\ ${ }^{2}$ Metastasis and Angiogenesis Research Group, Cardiff University School of Medicine, Cardiff CF14 4XN, UK; \\ ${ }^{3}$ Department of Urology, Peking University First Hospital, Beijing 100034, P.R. China; \\ ${ }^{4}$ Division of Translational Oncology, Crown Biosciences Inc., Santa Clara, CA 95054, USA; \\ ${ }^{5}$ Department of Urology, Central Hospital of HaMi Region in XinJiang Province, P.R. China
}

Received January 12, 2013; Accepted February 20, 2013

DOI: 10.3892/ijo.2013.1877

\begin{abstract}
Vascular endothelial growth inhibitor (VEGI) has been associated with tumor-related vasculature in certain malignancies. However, its implication in renal cell carcinoma (RCC), an angiogenesis-dependent tumor, remains unknown. In the present study, we investigated the role played by VEGI in RCC. The expression of VEGI was examined in human renal tissue and RCC cell lines using immunohistochemical staining and RT-PCR, respectively. The biological impact of modifying the expression of VEGI in RCC cells was evaluated using in vitro and in vivo models. We show that VEGI mRNA is expressed in a wide variety of human RCC cell lines, all of normal renal and most of RCC tissue specimens. VEGI protein expression was observed in normal renal tubular epithelial cells, but was decreased or absent in RCC specimens, particularly in tumors with high grade. Moreover, forced expression of VEGI led to an inhibition of vascular endothelial tube formation, decrease in the motility and adhesion of RCC cells in vitro. Interestingly, forced expression of VEGI had no bearing on growth, apoptosis and invasive capacity of RCC cells. However, tumor growth was reduced in xenograft models. Immunohistochemical staining showed that microvessel density decreased in VEGI forced expression
\end{abstract}

Correspondence to: Dr Yong Yang, Department of Urology, Beijing Chaoyang Hospital, Capital Medical University, 8 Gongti South Road, Chaoyang District, Beijing 100020, P.R. China

E-mail: niru7429@yahoo.com.cn

Dr Kan Gong, Department of Urology, Peking University First Hospital, Dahongluchang Street, Xicheng District, Beijing 100034, P.R. China

E-mail: gongkan0582@sina.com

*Contributed equally

Key words: vascular endothelial growth inhibitor, renal cell carcinoma, angiogenesis, target therapy xenograft tumor samples. Taken together, our findings showed that the expression of VEGI is decreased in RCC, particularly in tumors with higher grade. Together with its inhibitory effect on cellular motility, adhesion, vascular endothelial tube formation and tumor growth in vivo, this suggests that VEGI functions mainly through inhibition of angiogenesis and is a negative regulator of aggressiveness during the development and progression of RCC.

\section{Introduction}

Renal cell carcinoma (RCC), which accounts for $\sim 2-3 \%$ of all adult malignant neoplasm, is the most lethal of the common urologic cancers $(1,2)$. Traditionally, $30-40 \%$ of patients with RCC die of their cancer, in contrast to the $20 \%$ mortality rates associated with prostate and bladder carcinomas $(3,4)$. Over the past three decades, there has been an increase in the detection of renal tumors due to the widespread use of noninvasive imaging techniques such as ultrasound and computed tomography scan in the investigation of various non-specific symptoms (5). This trend has correlated with an increased proportion of incidentally discovered and localized tumors and with improved 5-year survival rates for patients with this stage of disease $(6,7)$. However, other factors must also be at play because Chow and colleagues have documented a steadily increasing mortality rate from RCC per unit population since the 1980s and this was observed in all ethnic and both gerders $(3,8)$. It has been reported that the incidence of advanced tumors per unit population has also increased; and the mortality rate per unit population has still been negatively affected $(3,8-10)$. In the European Union and the United States, between 46,000 and 63,000 new cases of RCC are diagnosed annually and $\sim 40 \%$ of RCC patients die from RCC-related causes each year (7). In the treatment of renal cell carcinoma, localized disease is curable by surgery, however, metastatic and locally advanced disease are considerably more difficult to treat $(11,12)$. Historically, therapeutic options for metastatic or for locally advanced RCC, primarily cytokine therapy, produced low response rates and considerable toxicity 
$(13,14)$. Moreover, it is well known that RCC is one of the most vascular of cancers as reflected by the distinctive neovascular pattern exhibited on renal angiography. Given the dependence of RCC on angiogenesis and the absence of generally effective forms of systemic therapies, it is not surprising that RCC has been targeted for anti-angiogenic approaches. Targeted agents (such as sorafenib, sunitinib malate, pazopanib, bevacizumab) are now well established for the treatment of patients with advanced or metastatic renal cell carcinoma $(7,15,16)$.

Although the targeted therapy is spread among a variety of new active drugs, so far complete cure is achieved very rarely (17). Experience has shown that the targeted therapies control tumor growth only temporarily and after a latency period that may vary according to the molecular characteristics of the tumor, the malignancy reappears. Resistance to targeted therapy may be caused by activation of alternative proangiogenic pathways, recruitment of bone marrow-derived proangiogenic cells, increased pericyte coverage of tumor vasculature and enhancement of invasion and metastasis (18-20). Additionally, host genomics may adversely affect drug metabolism, leading to poor activity or toxicities. However, there does not appear to be cross-resistance among these therapies and subsequent treatment lines can be beneficial. Therefore, finding a new target for anti-angiogenesis could be helpful for treating advanced and metastatic RCC (16).

Vascular endothelial growth inhibitor (VEGI) [also known as tumor necrosis factor superfamily member 15 (TNFSF15) and TNF ligand related molecule 1 (TL1)], a natural antiangiogenic factor, was first reported in 1999 from human umbilical vein endothelial cells (21-23). The full gene of VEGI is $\sim 17 \mathrm{~kb}$, which consists of four exons and three introns and is mapped to human chromosome 9q32. Three splicing variants of VEGI have been reported. Its transcript was found to be expressed in the placenta, lung, kidney, skeletal muscle, pancreas, spleen, small intestine, prostate and colon (23). The secreted soluble form of VEGI has been demonstrated as a potent anti-angiogenic factor through inhibiting proliferation of endothelial cells $(24,25)$. Previous studies have also shown that VEGI expression could significantly reduce motility and adhesion of prostate and bladder cancer cells $(26,27)$. Zhai et al and Xiao et al reported that VEGI markedly suppressed the growth of colon carcinoma cells (murine colon cancer cells, MC-38) both in vitro and in vivo $(23,28)$. Systemic administration of VEGI also markedly inhibited tumor growth and increased survival time in a Lewis lung cancer (LLC) murine tumor model suggesting that pro-apoptotic effect of soluble VEGI in endothelial cells is critical for its antitumor activity (28-32).

Despite these observations of VEGI in solid tumors, its role in RCC remains unknown. In the present study, the expression of VEGI was examined in human RCC and normal renal tissues and in RCC cell lines. The biological function of this molecule was investigated in vitro and in vivo, in which the expression of VEGI was manipulated by genetic methods.

\section{Materials and methods}

\section{Materials}

Mice. All female BALB/c mice (6-8 weeks, 18-22 g) were supplied by Shanghai Laboratory Animal Center [SLAC,
Shanghai, China, Animal Certificate No. SCXK (Hu) 2007-0005]. All the procedures related to animal handling, care and the treatment in this study were performed according to the guidelines approved by the Institutional Animal Care and Use Committee (IACUC) of CrownBio following the guidance of the Association for Assessment and Accreditation of Laboratory Animal Care (AAALAC).

Cell lines. All cell lines used in this study were purchased from the American Type Culture Collection (ATCC, Rockville, MD, USA). This study used human renal cell carcinoma cells (786-O, OS-RC-2, A-498, Caki-1), a human adrenal gland small cell carcinoma cell line (SW-13) and a human umbilical vein endothelial cell line (HUVEC). Cells were routinely cultured with Dubecco's modified Eagle's medium (DMEM) supplemented with $10 \%$ fetal calf serum, penicillin and streptomycin (Gibco BRC, Paisley, UK).

Human renal cell carcinoma specimens. A total of 23 pairs renal cell carcinoma and normal renal tissue samples were snap-frozen in liquid nitrogen immediately after open radical nephrectomy. The pathologist verified normal and cancer specimens. All protocols were reviewed and approved by the local ethics committee and all patients gave written informed consent.

RNA isolation and reverse transcription PCR. RNA was isolated using Total RNA Isolation reagent (ABgene, Epsom, UK). First strand cDNA was synthesized from $0.5 \mu \mathrm{g}$ RNA using a reverse transcription kit (Sigma, Poole, Dorset, UK). The quality of cDNA was verified through the amplification and detection of the GAPDH housekeeping gene. VEGI forward and reverse primers (Table I) were designed based on the human VEGI sequence (GeneBank accession no. BD131562). PCR was performed in a GeneAmp PCR system 2400 thermocycler (Perkin-Elmer, Norwalk, CT, USA). Conditions for PCR were $40 \mathrm{sec}$ at $94^{\circ} \mathrm{C}, 60 \mathrm{sec}$ at $55^{\circ} \mathrm{C}, 60 \mathrm{sec}$ at $72^{\circ} \mathrm{C}$ ( 35 cycles). PCR products were separated on a $1.4 \%$ agarose gel.

IHC staining of human renal and xenograft tumor specimens. Frozen specimens of renal cell carcinoma $(n=23)$, normal renal tissue $(n=23)$ and xenograft tumors $(n=24)$ were cut at a thickness of $6 \mu \mathrm{m}$ using a cryostat (Leica CM 1900, Leica Microsystems UK Ltd., Buckinghamshire, UK). The nature of the samples was independently verified by two pathologists. After fixation, the sections were blocked with horse serum and probed with or without VEGI antibody (SC-53975) for $1 \mathrm{~h}$. The secondary biotinylated antibody and the avidin-biotin complex were subsequently applied to detect VEGI expression in accordance with the Vectastain Universal Elite ABC kit protocol (Vector Laboratories, Peterborough, UK). After developing color with DAB, the sections were counterstained with Gill's hematoxylin. Staining was independently assessed by the authors. The monoclonal mouse anti-human-VEGI and anti-human-VEGFR2 antibodies were purchased from LSBio Inc. (LS-C76815 and LS-C92359, respectively, LSBio Inc., Seattle, WA, USA). Monoclonal mouse anti-human-Ki67 and anti-human-CD31 (PECAM) antibodies were purchased from Santa Cruz Biotechnology, Inc. (SC-56320 and SC-133091 respectively, Santa Cruz, CA, USA). 
Table I. Primer sequences for PCR.

\begin{tabular}{|c|c|c|}
\hline Primer & Forward & Reverse \\
\hline hGAPDH & 5'-AGCTTGTCATCAATGGAAAT-3' & 5'-CTTCACCACCTTCTTGATGT-3' \\
\hline hGAPDH (qPCR) & 5'-CTGAGTACGTCGTGGAGTC-3' & $\begin{array}{l}\text { 5'-ACTGAACCTGACCGTACA } \\
\text { CAGAGATGATGACCCTTTTG-3' } \\
\text { Z-sequence }\end{array}$ \\
\hline VEGI & 5'-ATGAGACGCTTTTTAAGCAA-3' & 5'-CTATAGTAAGAAGGCTCCAAAG-3' \\
\hline VEGI (qPCR) & 5'-CAAAGTCTACAGTTTCCCAAT-3' & $\begin{array}{l}\text { 5'-ACTGAACCTGACCGTACA } \\
\text { TGATTTTTAAAGTGCTGTGTG-3' } \\
\text { Z-sequence }\end{array}$ \\
\hline VEGI (ribozyme 2) & $\begin{array}{l}\text { 5'-CTGCAGTCTCACAACTGGAAACT } \\
\text { GATGAGTCCGTGAGGA-3' }\end{array}$ & $\begin{array}{l}\text { 5'-ACTAGTTAATCCTCTTTCTTGTTT } \\
\text { CGTCCTCACGGACT-3' }\end{array}$ \\
\hline VEGI (expression) & 5'-ATGAGACGCTTTTTAAGCAA-3' & 5'-CTATAGTAAGAAGGCTCCAAAGA-3' \\
\hline $\begin{array}{l}\text { Primers for } \\
\text { detecting plasmid }\end{array}$ & T7F: TAATACGACTCACTATAGGG & BGHR: TAGAAGGCACAGTCGAGG \\
\hline $\begin{array}{l}\text { Primers to } \\
\text { detect ribozymes }\end{array}$ & RBTPF: CTGATGAGTCCGTGAGGACGAA & RBBMR: TTCGTCCTCACGGACTCATCAG \\
\hline
\end{tabular}

Western blot analysis of VEGI expression. Protein concentration in cell lysates were determined using the DC Protein Assay kit (Bio-Rad) and an ELx800 spectrophotometer (Bio-Tek ${ }^{\mathrm{TM}}$ ). Equal amount of proteins were separated by sodium dodecyl sulfate-polyacrylamide gel electrophoresis (SDS-PAGE) and blotted onto nitrocellulose sheets. Proteins were then probed with the VEGI antibody $(1: 1,500)$ and peroxidase-conjugated secondary antibodies. Monoclonal mouse anti-human- $\beta$-actin (1:1,000, SC-130301, Santa Cruz) was used as a housekeeping control. Protein bands were visualized using the Supersignal ${ }^{\mathrm{TM}}$ West Dura system (Pierce Biotechnology, Inc., Rockford, IL, USA) and photographed using an UVITech imager (UVITech, Inc., Cambridge, UK).

Construction of VEGI expressing and ribosome transgenes and transfection. The full-length human VEGI coding sequence and hammer-head ribozymes targeting human VEGI was cloned into a mammalian expression plasmid vector (pEF/His TOPO TA, Invitrogen, Inc., Paisley, UK). Full primer sequences are provided in Table I. The recombinant plasmid vectors were transformed into chemically competent TOP10 E. coli (Invitrogen). After verification and amplification, empty control plasmids or plasmids containing VEGI expression sequence or ribozyme transgenes were then transfected into 786-O, SW-13 and SC-OR-2 cells using electroporation (Easyjet, EquiBio Ltd., Kent, UK). After selection with blasticidin, the transfectants were used used for subsequent analysis.

Real-time quantitative polymerase chain reaction ( $q P C R$ ). Real-time quantitative PCR was carried out using the iCycler ${ }^{\mathrm{iQ5}}$ system (Bio-Rad, Hemel Hemstead, UK) to determine the level of expression of the VEGI transcripts in the cell lines. GAPDH was used as a housekeeping control.
Cell growth assay. This was based on a method we previously described (33). Briefly, cells were plated into a 96-well plate (2,500 cells/well). Cell growth was assessed after 1, 3 and 5 days. Crystal violet was used to stain cells and absorbance was determined at a wavelength of $540 \mathrm{~nm}$ using a spectrophotometer (Bio-Tek, Elx800, UK).

Flow cytometric analysis of apoptosis. All cells including those floating in the culture medium were harvested after a period of incubation. The apoptotic population of the cells was determined using Vybrant ${ }^{\circledR}$ Apoptosis Assay kit (Invitrogen) and flow cytometry $\left(\mathrm{CyFlow}^{\circledR} \mathrm{SL}\right.$, Partec GmbH, Münster, Germany).

Wounding assay. The migration of cells in a monolayer across a wounded surface of a near-confluent cell monolayer was examined. Cells at a density of 50,000/well were seeded into a chamber slide and allowed to reach near confluence. The monolayer of cells was then scraped with a fine gauge needle to create a wound of $\sim 200 \mu \mathrm{m}$. The movement of cells to close the wound was recorded using a time lapse video recorder and analysed using the motion analysis feature of the Image $\mathbf{J}$ software (NIH, USA).

Motility assay using Cytodex-2 beads. Cells $\left(1 \times 10^{6}\right)$ were incubated with $100 \mu \mathrm{l}$ of cytocarrier beads overnight. The beads were washed twice to remove dead cells and then resuspended. Beads/cells $(100 \mu \mathrm{l})$ were transferred into each well of a 24-well plate. After incubation for $4 \mathrm{~h}$, the cells were fixed in $4 \%$ formalin and stained with $0.5 \%$ crystal violet before counting.

Invasion assay. This was modified from a method we prevously described (33). Transwell inserts with $8-\mu \mathrm{m}$ pore 
size were coated with $50 \mu \mathrm{g}$ Matrigel (BD Matrigel ${ }^{\mathrm{TM}}$ basement membrane matrix) and air-dried. After rehydration, 20,000 cells were added to each well. After $96 \mathrm{~h}$ cells that had migrated through the matrix to the other side of the insert were fixed, stained and then counted under a microscope.

Cell-matrix adhesion assay. Cell-matrix adhesion was assessed in a standard manner. Cells $(40,000)$ were added in each well of 96-well plate, previously coated with Matrigel (5 $\mu \mathrm{g} / \mathrm{well})$. After $40 \mathrm{~min}$ of incubation, non-adherent cells were washed off using BSS buffer. The remaining adherent cells were then fixed and stained with crystal violet. The number of adherent cells was then counted.

Endothelial cell differentiation assay: tube formation on Matrigel (34). This was based on a Matrigel-sandwich tubule forming assay developed in our laboratory. Briefly, $200 \mu \mathrm{g}$ of cold Matrigel solution dispersed in $100 \mu \mathrm{l}$ (Becton-Dickinson, Bristol, UK) was added to a 96-well plate and allowed to air-dry at $37^{\circ} \mathrm{C}$. Following rehydration of Matrigel, it formed a thin bottom layer. HUVEC cells $\left(2.5 \times 10^{4}\right)$ per well were seeded onto a 96-well plate and allowed to attach to the bottom of the well (4-6 h). After that, $200 \mu \mathrm{g}$ of cold Matrigel solution dispersed in $100 \mu \mathrm{l}$ was loaded to each well again, followed by incubation at $37^{\circ} \mathrm{C}$ for $3 \mathrm{~h}$ when the second layer of Matrigel solidified. Finally, 10,000 tested cells (different renal cell carcinoma cell lines) were added and incubated at $37^{\circ} \mathrm{C}$ in a humidified chamber with $5 \% \mathrm{CO}_{2}$. Following incubation for 7 or $20 \mathrm{~h}$, cultures were observed and photographed (Nikon, Tokyo, Japan).

Tumor xenografts in $\mathrm{Nu} / \mathrm{Nu}$ nude mice. Twenty-four mice were divided into three groups $\left(786-\mathrm{O}^{\mathrm{wt}} \mathrm{Group}, 786-\mathrm{O}^{\mathrm{pEF} / \mathrm{His}}\right.$ Group and 786-O ${ }^{\text {VEGIexp4 }}$ Group). Each mouse was inoculated subcutaneously at the right flank with $786-\mathrm{O}$ cells $\left(5 \times 10^{6}\right)$ in $0.1 \mathrm{ml}$ of PBS for tumor development. The mice were kept in individually ventilated cage (IVC) systems at constant temperature and humidity with 4 animals in each cage. The date of tumor cell inoculation was denoted as day 0 . The data of tumor growth and normal behavior such as mobility, visual estimation of food and water consumption, body weight gain/ loss (body weights were measured twice weekly), eye/hair matting and any other abnormal effect were collected every three days. Tumor sizes were measured each three days in two dimensions using a caliper and the volume was expressed in $\mathrm{mm}^{3}$ using the formula: $\mathrm{V}=0.5 a \times b^{2}$ where $a$ and $b$ were the long and short diameters of the tumor, respectively.

Statistical analysis and software. The mean optical density (MOD) feature of RT-PCR and western blot analysis was analysed using software package Image-Pro Plus 6.0 (Media Cybernetics, USA). The method was as follows: every image prepared for comparison was changed to grayscale image. Then, selecting ten points in the comparison region randomly, the MOD of the point was analyzed using the software. The length of cell migration and HUVEC was measured by software Image $\mathbf{J}(\mathrm{NIH})$. The distance of HUVEC cells was calculated along the long axes in each compared image.
All statistical analysis was performed using the SPSS 16.0 software. Two sample t-tests was used for normally distributed data. Fisher's exact test was used for analyzing immunohistochemical staining in renal tissues. Differences were considered to be statistically significant at $\mathrm{P}<0.05$.

\section{Results}

The expression of VEGI in renal cell carcinoma cell lines and renal tissues. The expression of VEGI was examined in four renal cell carcinoma cell lines, adrenal gland cell line and human renal tissues using conventional RT-PCR. VEGI transcript was detectable in all five cell lines (Fig. 1A). It was also detected more frequently in normal renal tissues $(23 / 23)$ than that in renal cell carcinoma tissues (15/23), $\mathrm{P}<0.01$ (Fig. 1B). Moreover, the expression of VEGI transcript was stronger in normal renal tissues $(\mathrm{MOD}=0.87 \pm 0.13)$ than that in renal cell carcinoma tissues $(\mathrm{MOD}=0.24 \pm 0.17), \mathrm{P}<0.01$. Furthermore, in immunohistochemical staining, VEGI was seen in normal renal tubular epithelia cells, but the staining was decreased or absent in renal cell carcinoma cells, particularly in the specimen with higher grade (Fig. 1C). The positive staining of normal tissue $(100 \%, 23 / 23)$ was significantly higher than that of renal cell carcinoma tissues $(34.78 \%, 8 / 23), \mathrm{P}<0.01$. The MOD of normal renal tissues $(0.49 \pm 0.15)$ was higher than that of renal cell carcinoma tissues $(0.11 \pm 0.05)$ either, $\mathrm{P}<0.01$.

Genetic manipulation of VEGI levels in RCC cell lines. 786-O, which expressed modest level of VEGI transcript, were transfected with a VEGI expression construct and anti-VEGI ribozyme transgenes, to respectively create sublines showing enhanced or suppressed levels of VEGI expression. OS-RC-2 and SW-13, which expressed lower level of VEGI transcript, was only transfected with the VEGI expression construct. As shown by RT-PCR analysis, VEGI mRNA expression was increased in 786-O $\mathrm{O}^{\text {VEGIexp4 }}$, OS-RC-2 $2^{\text {VEGIexp4 }}$ and SW-13 ${ }^{\text {VEGIexp4 }}$ cells, compared to wild-type (786-O ${ }^{\mathrm{wt}}$, OS-RC-2 ${ }^{\mathrm{wt}}$ and SW-13 ${ }^{\mathrm{wt}}$ ) and plasmid control (786- $\mathrm{O}^{\mathrm{pEF} / \mathrm{His}}, \mathrm{OS}-\mathrm{RC}-2^{\mathrm{pEF} / \mathrm{His}}$ and $\mathrm{SW}-13^{\mathrm{pEF} /}$ His) cells (Fig. 2A). However, VEGI mRNA expression in the $786-\mathrm{O}^{\text {VEGIrib2 }}$ cells was lower than that in $786-\mathrm{O}^{\text {wt }}$ cells, but was similar to that in $786-\mathrm{O}^{\mathrm{pEF} / \mathrm{His}}$ cells, suggesting that the ribozyme is ineffective (Fig. 2A). Moreover, according to the results of qPCR, VEGI mRNA expression was dramatically increased in 786-O ${ }^{\text {VEGIexp4 }}$, OS-RC-2 $2^{\text {VEGIexp4 }}$ and SW-13 ${ }^{\text {VEGIexp4 }}$ cells, but did not decrease in 786-O $\mathrm{O}^{\text {VEGIrib2 }}$ cells, compared with corresponding controls (Fig. 2B). Comparing with controls, an increase in the VEGI protein level was also seen in 786-O $\mathrm{O}^{\text {VEGIexp4 }}$ cells in western blot analysis (Fig. 2C). However, there was no significant difference in VEGI protein level between $\mathrm{SW}-13^{\text {VEGIexp4 }}$ and OS-RC-2 ${ }^{\text {VEGIexp4 }}$ cells and their controls. Therefore, we chose the 786-O cell lines to perform our following test.

Manipulation of VEGI expression had no impact on growth, apoptosis and invasiveness of RCC cells. First, we examined the effect on growth, apoptosis and invasiveness of 786-O cell lines by VEGI. The growth (Fig. 3A) and invasion (Fig. 3B) of 786-O ${ }^{\text {VEGIexp4 }}$ cells did not show any difference from that of wildtype and empty plasmid control cells $(\mathrm{P}>0.05)$. Furthermore, we did not find a difference in the apoptotic populations between cells with VEGI forced expression and control cells $(\mathrm{P}>0.05)$ (Fig. 3C). 

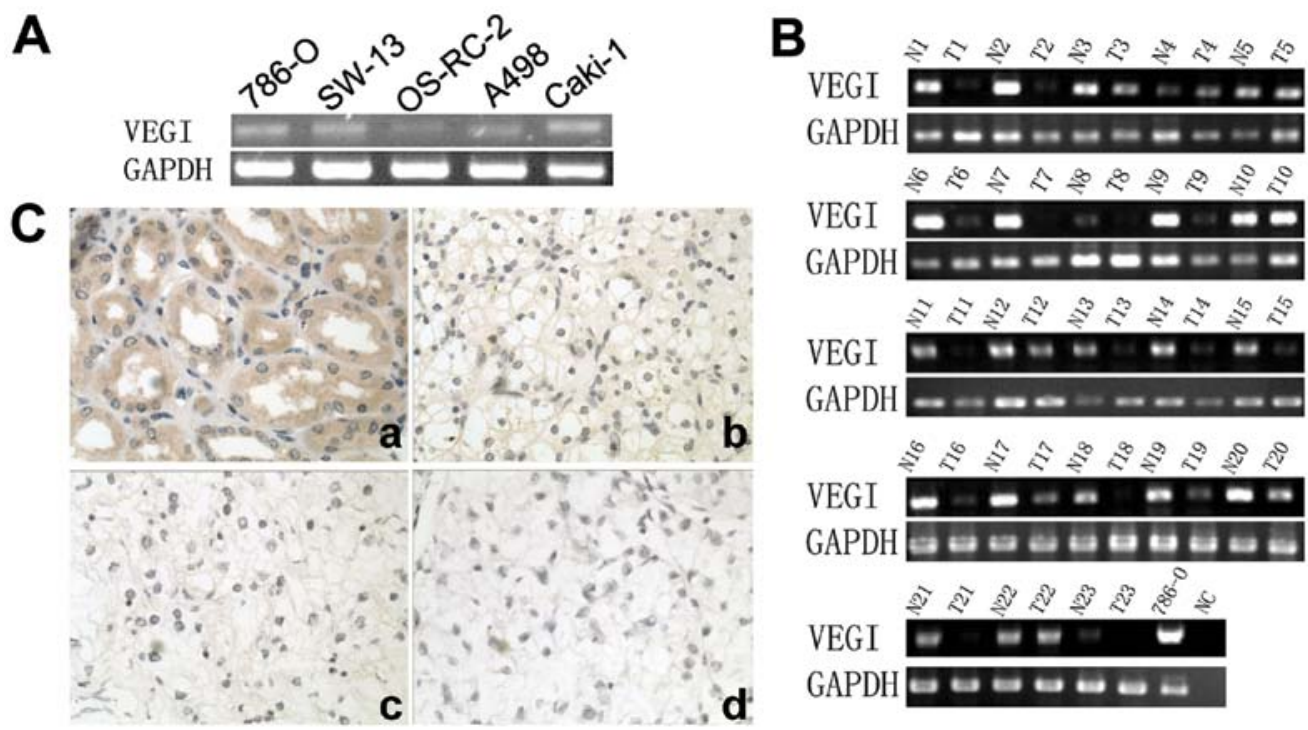

Figure 1. VEGI expression in renal tissues and cell lines. (A) Detection of the VEGI transcript using RT-PCR in five cell lines. (B) Detection of the VEGI transcript in a panel of tumor and normal renal tissues. GAPDH was used as the house-keeping control. N, normal. T, tumor. (C) Immunohistochemical staining of human renal specimens. (a) Normal renal tissues. The VEGI protein was found to be intensively stained in the cytoplasmic area of normal renal tubular epithelia cells. (b) Renal cell carcinoma tissues with nuclear grade 1. VEGI was weakly stained in these cells than those in normal cells. (c) Renal cell carcinoma tissues with nuclear grade 2. VEGI was weakly stained in these cells. (d) Renal cell carcinoma tissues with nuclear grade 3 . The VEGI protein staining was nearly absent. That is, VEGI expression was seen to be negative or weakly positive in the cancer cells of renal cell carcinoma tissue.
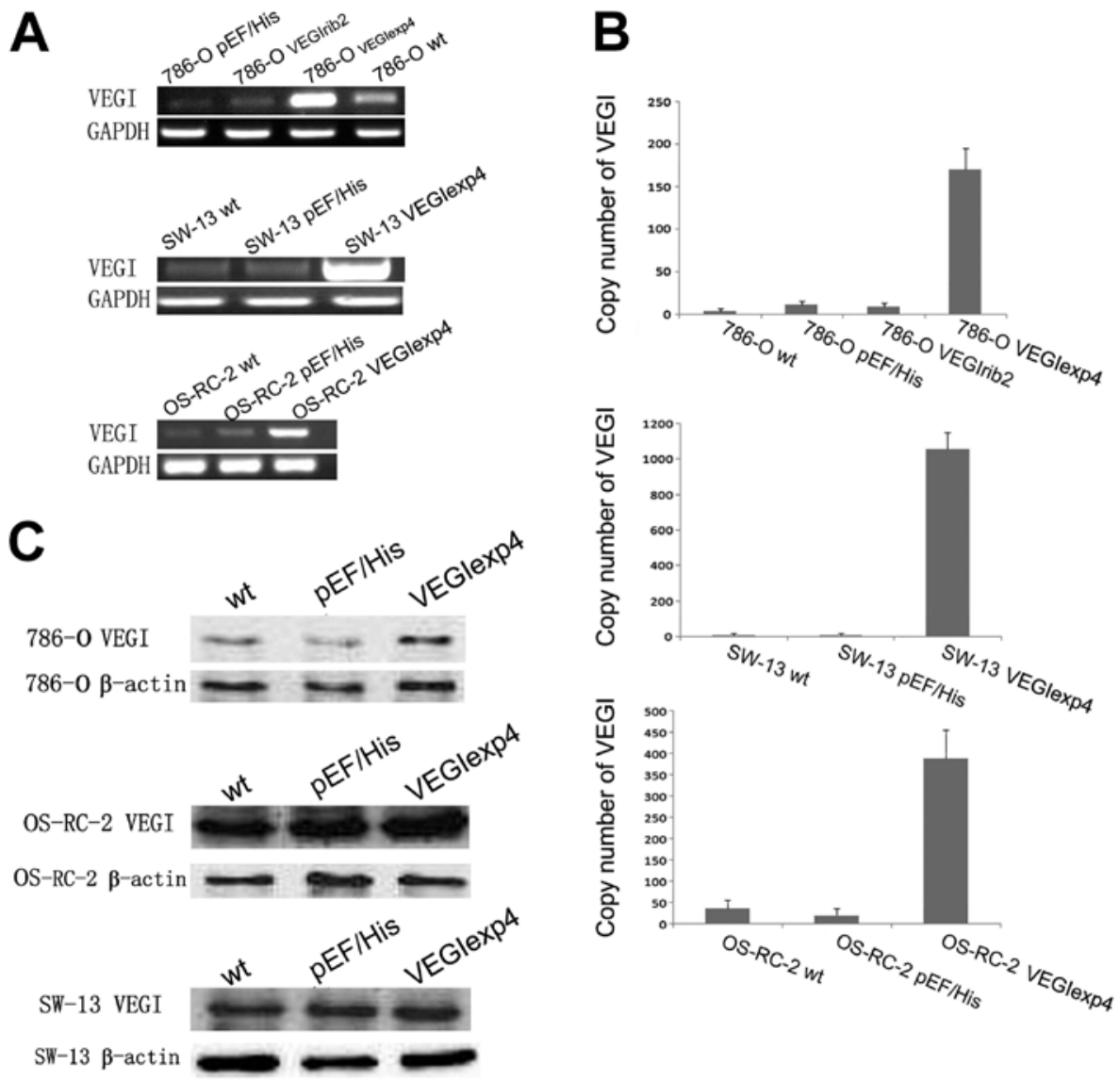

Figure 2. Confirmation of manipulation of VEGI expression in renal cell carcinoma cells. (A) Verification of forced expression of the VEGI transcript in 786-O, SW-13 and OS-RC-2 cells. VEGI mRNA expression in the 786- $\mathrm{O}^{\text {vEGIrib2 }}$ cells was lower than that in $786-\mathrm{O}^{\mathrm{wt}}$ cell, but was similar to that in $786-\mathrm{O}^{\mathrm{pEF} / \mathrm{His}}$ cells, suggesting that the ribozyme is ineffective. Representative image from 4 experiments show results of the RT-PCR. (B) Verification of forced expression of VEGI transcript in 786-O, SW-13 and OS-RC-2 cells, using Q-PCR. VEGI mRNA expression was dramatically increased in 786-O $\mathrm{O}^{\text {VEGlexp4 }}$, OS-RC-2 $^{\text {VEGGexp4 }}$ and SW-13 ${ }^{\text {VEGIexp4 }}$ cells, but did not decrease in 786- $\mathrm{O}^{\text {VEGIrib2 }}$ cells, compared with the wild-type and empty plasmid control cells. The error bars represent standard deviations. (C) Force expression of VEGI at protein level using western blot analysis for 786-O, SW-13 and OS-RC-2 cells. VEGI protein level was increased in 786- $\mathrm{O}^{\text {vEGlexp4 }}$ cells compared to that of wild-type and empty plasmid control cells. However, there was no significant difference in VEGI protein level between SW-13 ${ }^{\text {VEGIexp4 }}$ and OS-RC-2 ${ }^{\text {VEGlexp4 }}$ cells and their controls. 

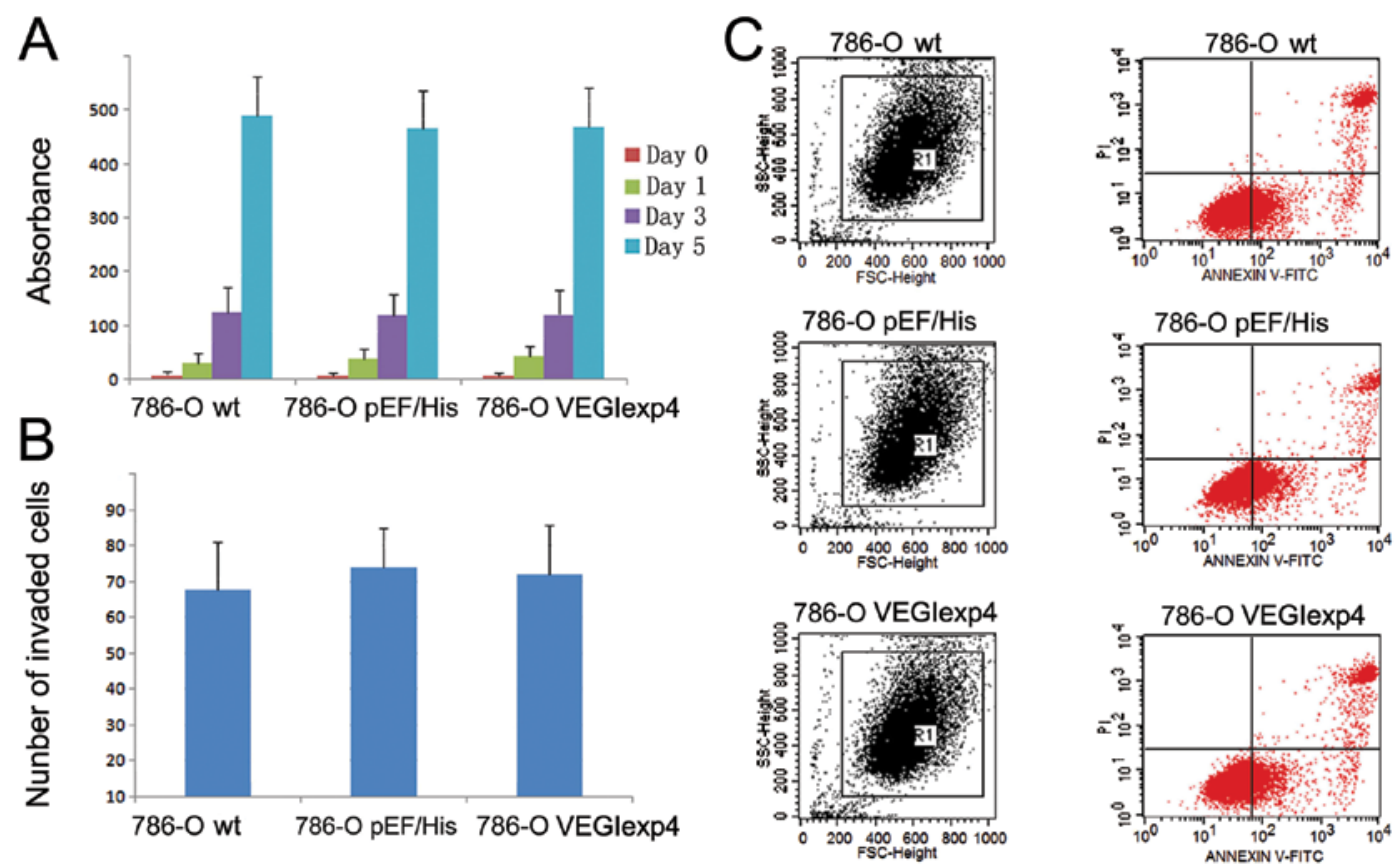

Figure 3. The effect of VEGI forced expression on growth, invasiveness and apoptosis of 786-O cells. (A) The growth capacity of 786-O ${ }^{\mathrm{vEGiexp} 4}$ cells did not show any difference from that of wild-type and empty plasmid control cells $(\mathrm{P}>0.05)$. (B) The invasiveness of $786-\mathrm{O}^{\mathrm{vEGlexp} 4}$ cells did not show any difference from that of wild-type and empty plasmid control cells $(\mathrm{P}>0.05)$. (C) There was no difference in the apoptotic populations between cells with VEGI forced expression and control cells $(\mathrm{P}>0.05)$. The error bars represent standard deviations.
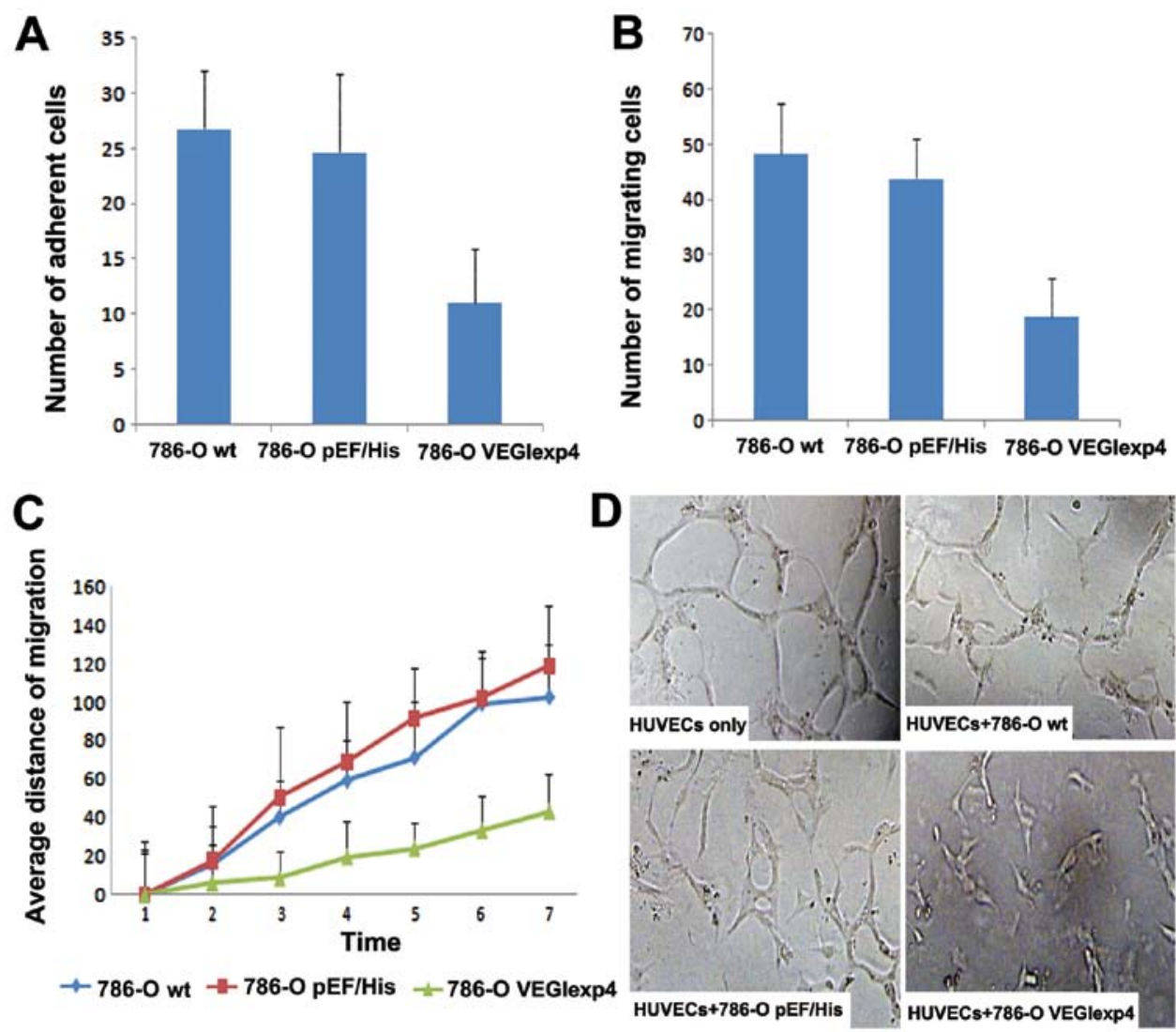

Figure 4. The effect of VEGI forced expression on cell matrix adhesion, migration and vascular endothelial tube formation. (A) VEGI expression and in vitro cell-matrix adhesion. All experiments were repeated 5 times. Forced expression of VEGI reduced the number of adherent cells in $786-\mathrm{O}^{\mathrm{VEGIexp} 4}$ cells $(\mathrm{P}<0.01)$. Error bars represent the SD. (B) The effect of forced expression of VEGI on migration of 786-O $\mathrm{O}^{\text {VEGlexp4 }}$ cells. All experiments were repeated 4 times. The motility of 786-O $\mathrm{O}^{\text {vEGiexp4 }}$ cells was markedly reduced, compared with wild-type and empty plasmid control cells $(\mathrm{P}<0.01)$. Experiments were done in 6-wells per cell type. Error bars represent the SD. (C) The effect of forced expression of VEGI on migration assay (scratch wounding assay). All experiments were repeated 3 times. The movement was reduced significantly in 786- $\mathrm{O}^{\text {VEGIexp4 }}$ cells compared with wild-type and empty plasmid control cells $(\mathrm{P}<0.01)$. Error bars represent the SD. (D) The effect of forced expression of VEGI on vascular endothelial tube formation. Compared to controls, when HUVECs with 786-O ${ }^{\text {VEGIexp4 }}$ were co-cultured, the tube formation decreased significantly. The cells collected together showing poor ductibility. 


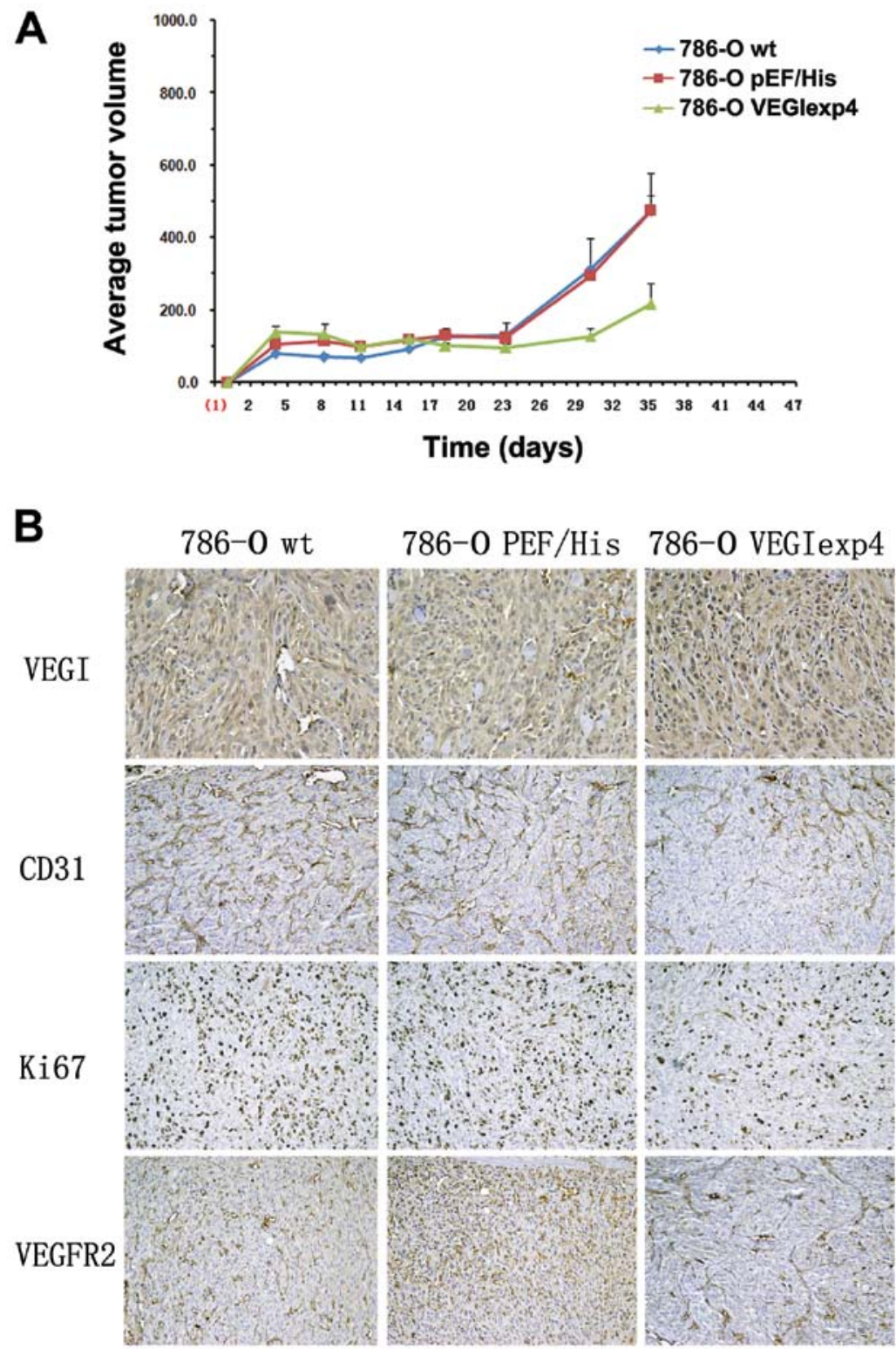

Figure 5. The effect of VEGI forced expression on xenograft models and angiogenesis in xenograft models. (A) The effect of forced expression of VEGI on xenograft models. Three weeks after successful establishment of xenograft models, tumor volume was found significantly reduced in the group of BALB/c nude mice injected with 786- $\mathrm{O}^{\mathrm{VEGlexp} 4}$ cells, compared with $786-\mathrm{O}^{\mathrm{wt}}, 786-\mathrm{O}^{\mathrm{pEF} / \mathrm{His}}$ cells $(\mathrm{P}<0.01)$. Error bars represent the SD. (B) The effect of VEGI forced expression on angiogenesis in xenograft models. In IHC, comparing with 786- $\mathrm{O}^{\mathrm{wt}}$ and $786-\mathrm{O}^{\mathrm{pEF} / \mathrm{His}}$ cells, VEGI staining was increased in samples from xenograft tumors with 786- $\mathrm{O}^{\text {VEGlexp4 }}$ cells $(\mathrm{P}<0.01)$. However, comparing with $786-\mathrm{O}^{\mathrm{wt}}$ and $786-\mathrm{O}^{\mathrm{pEF} / \mathrm{His}}$ cells, Ki67 and VEGFR2 expression was decreased, respectively, in tumors with $786-\mathrm{O}^{\text {VEGlexp4 }}$ cells $(\mathrm{P}<0.01)$. Significant reduction in microvessel density, as indicated by reduced $\mathrm{CD} 31$ staining, was observed in 786- $\mathrm{O}^{\text {VEGIexp4 }}$ tumors compared to that in $786-\mathrm{O}^{\mathrm{wt}}$ and $786-\mathrm{O}^{\mathrm{pEF} / \mathrm{His}}$ tumors $(\mathrm{P}<0.01)$.

The influence of VEGI expression on cell matrix adhesion and motility of 786-O cells. In this step, we examined the effect on cell-matrix adhesion of 786-O cell lines by VEGI. Overexpression of VEGI exhibited a significant inhibitory effect on cell-matrix adhesion of the cells. Compared with $786-\mathrm{O}^{\mathrm{wt}}(26.84 \pm 5.19)$ and $786-\mathrm{O}^{\mathrm{pEF} / \mathrm{His}}(24.72 \pm 7.01)$, the number of adherent cells for $786-\mathrm{O}^{\text {VEGlexp4 }}(11.13 \pm 4.88)$ was significantly reduced ( $\mathrm{P}<0.001$ vs both controls) (Fig. 4A).

In the cytocarrier based cell motility assay, we found that cell motility was reduced significantly in 786- $\mathrm{O}^{\text {VEGIexp4 }}$ cells. The number of migrating $786-\mathrm{O}^{\text {VEGIexp4 }}$ cells was $18.92 \pm 6.88$ compared with $48.31 \pm 9.19$ for $786-\mathrm{O}^{\mathrm{wt}}$ cells and $43.97 \pm 7.01$ for 786- $\mathrm{O}^{\mathrm{pEF} / \mathrm{His}}$ cells (Fig. 4B) (both $\mathrm{P}<0.01$ ). To further investigate the effect of forced expression of VEGI on cell motility, wounding assay was used. We also found that the motility was reduced significantly in cells containing the VEGI expression construct. The average migrating distance of 786- $\mathrm{O}^{\text {VEGIexp4 }}$ was $43.35 \pm 19.65 \mu \mathrm{m}, \mathrm{P}<0.01$ compared to both $786-\mathrm{O}^{\text {wt }}$ $(102.39 \pm 27.42 \mu \mathrm{m})$ and $786-\mathrm{O}^{\mathrm{pEF} / \mathrm{His}}(118.71 \pm 31.81 \mu \mathrm{m})$ cells (Fig. 4C).

Inhibition of vascular endothelial tube formation by forced expression of VEGI. Single HUVECs, when cultured between the Matrigel layers, were seen to form typical tube-like structures after $20 \mathrm{~h}$. Fig. 4D shows that the lumen was composed of several endothelial cells linked to each other. When HUVECs with $786-\mathrm{O}^{\mathrm{wt}} / 786-\mathrm{O}^{\mathrm{pEF} / \mathrm{His}}$ were co-cultured, a proportion of cells formed an incomplete lumen. The cells still had suffi- 
cient ductibility. However, when HUVECs with 786-O ${ }^{\text {VEGIexp4 }}$ co-cultured, the tube formation decreased significantly in comparison with controls (Fig. 4D). The cells collected together with poor ductibility. The distance of HUVECs in each field co-cultured with 786-O VEGIexp4 $^{\text {(1.29E-04 }}$ 5.5E-06) was significantly decreased, compared with HUVECs co-cultured with $786-\mathrm{O}^{\mathrm{wt}} / 786-\mathrm{O}^{\mathrm{pEF} / \mathrm{His}}$ and HUVECs only (2.44E-04 $\pm 9.1 \mathrm{E}-06,2.48 \mathrm{E}-04 \pm 9.9 \mathrm{E}-06,2.58 \mathrm{E}-04 \pm 1.8 \mathrm{E}-06$, respectively) $(\mathrm{P}<0.01)$.

Reduced tumor growth in xenograft models from 786-O cells with forced expression of VEGI. To examine the effect of VEGI on tumor growth, xenograt models were successfully established in BALB/c nude mice by subcutaneous injection of 786- $\mathrm{O}^{\mathrm{wt}}, 786-\mathrm{O}^{\mathrm{pEF} / \mathrm{His}}$ and $786-\mathrm{O}^{\text {vEGlexp4 }}$ cells. Tumor volume was found significantly reduced in the group of BALB/c nude mice injected with $786-\mathrm{O}^{\text {VEGlexp4 }}$ cells $\left(216 \pm 146 \mathrm{~mm}^{2}\right)$, compared with $786-\mathrm{O}^{\mathrm{wt}}, 786-\mathrm{O}^{\mathrm{pEF} / \mathrm{His}}$ cells $(473 \pm 298$ and $475 \pm 115 \mathrm{~mm}^{2}$, respectively), $\mathrm{P}<0.01$ (Fig. 5A).

Reduced angiogenesis in xenograft models from 786-O cells with forced expression of VEGI. In immunohistochemical staining with samples from xenograft tumor, comparing with $786-\mathrm{O}^{\mathrm{wt}}$ and $786-\mathrm{O}^{\mathrm{pEF} / \mathrm{His}}$ cells, VEGI staining was increased in tumors with $786-\mathrm{O}^{\text {veGlexp4 }}$ cells (MOD was $0.45 \pm 0.22$, $0.39 \pm 0.15$ and $0.67 \pm 0.19$, respectively, $\mathrm{P}<0.01$ ) (Fig. 5B) Significant reduction in microvessel density, as indicated by reduced CD31 staining, was observed in 786-O $\mathrm{O}^{\text {VEGIexp4 }}$ tumors compared to that in $786-\mathrm{O}^{\mathrm{wt}}$ and $786-\mathrm{O}^{\mathrm{pEF} / \mathrm{His}}$ tumors $(87 \pm 21$, $211 \pm 43$ and $189 \pm 33$ respectively, $\mathrm{P}<0.01$ ) (Fig. 5B). Moreover, comparing with $786-\mathrm{O}^{\mathrm{wt}}$ and $786-\mathrm{O}^{\mathrm{pEF} / \mathrm{His}}$ tumors, Ki67 $(284 \pm 41,331 \pm 29$ and $119 \pm 37, \mathrm{P}<0.01)$ and VEGFR2 $(377 \pm 41$, $321 \pm 29$ and $144 \pm 24, \mathrm{P}<0.01)$ expression were also decreased in 786-O ${ }^{\text {VEGIexp4 }}$ tumors (Fig. 5B).

\section{Discussion}

VEGI, first identified from human umbilical vein endothelial cells is known to exist abundantly in arterial endothelial cells $(21,22)$. Subsequently, it has been reported that VEGI is also expressed in a wide variety of human cancer cell lines, including breast, prostate, bladder, colorectal and liver (24,35-38). The role of VEGI in human cancer cells has been investigated. According to the literature, it is able to induce apoptosis in endothelial cells via an autocrine pathway (22-25). Overexpression of VEGI has been shown to inhibit tumor neovascularisation and progression in cellular and animal models. Chew et al reported that overexpression of VEGI induced apoptosis in endothelial cells and inhibited the growth of xenograft tumors, together with a reduction in the microvessel density (24). Zhai et al found that the recombinant VEGI protein could markedly inhibit the growth of breast and colon xenograft tumors and suggested that the effect may be through an indirect inhibition on capillary-like structures and cells growth (23). Hou et al, using a Lewis lung cancer (LLC) murine tumor model, demonstrated that systemic administration of VEGI gave rise to a marked inhibition of tumor growth and to an increase in survival time of the treated animals (29). Further investigation has shown that the density of the endothelial cells exhibited an $88 \%$ decrease within 1 week of treatment with recombinant human VEGI and a further decrease within 3 weeks in Lewis lung cancer murine tumor models. Parr et al reported that patients with breast tumors expressing reduced levels of VEGI had a higher local recurrence, shorter survival time and an overall poorer prognosis than those patients expressing high levels of VEGI (39). Chen et al also reported that purified rhVEGI-192 potently inhibited endothelial growth, induced endothelial apoptosis and suppressed neovascularization in chicken chorioallantoic membrane and demonstrated that VEGI-192 is capable of forming polymeric structure, which is possibly required for its anti-angiogenic activity (40). Liang et al reported that VEGI inhibits bone marrow (BM)-derived endothelial progenitor cells (EPC) mobilization and prevents their incorporation into LLC tumors by inducing apoptosis specifically of BM-derived cells, resulting in the inhibition of EPC-supported tumor vasculogenesis and tumor growth (41). Overall, the above evidence indicated that the antitumor activity of VEGI is more likely to be the result of an interference with the development of tumor associated vasculature. However, many reports have also suggested that VEGI may inhibit the growth of some human tumor cell lines, including human histiocytic lymphomas (U-937), human breast carcinomas (MCF-7), human epithelial carcinoma (HeLa) and human myeloid lymphomas ML-1a $(28,42)$. Our previous results also show that the overexpression of VEGI can directly affect the motility and adhesion of urothelial tumor and prostate cancer cells $(26,27)$.

Given the dependence of RCC on angiogenesis and the mechanisms of target therapy, it is speculated that VEGI may be an effective target in treating RCC. The present study demonstrated exciting evidence supporting our hypothesis.

First of all, VEGI mRNA was expressed in a wide variety of human RCC cell lines, all the normal renal specimens and a proportion of the RCC specimens. It is obviously that VEGI transcript expression is at lower level in RCC tissues than that in normal renal tissues. The immunohistochemical analysis clearly indicates a similar trend. VEGI protein was found to be expressed at lower level in RCC tissues than that in normal renal tissues and was almost absent in tumors with high grade. The absence or reduction of tumor VEGI expression suggests that there may be a shift in the balance between pro- and anti-angiogenic stimuli. This loss of balance may subsequently produce a microenvironment that is conducive to tumor growth and survival.

Moreover, our results confirm that forced-expression of VEGI was able to directly affect the motility and adhesion of 786-O cells. The number of adherent cells in VEGI forced-expression cells was $>50 \%$ decreased compared with the wild-type cells. The average distance of VEGI expression cells was also decreased dramatically compared with controls. Therefore, VEGI can directly reduce aggressiveness of renal cancer cells, which is in line with the decreased expression of VEGI in RCC specimens.

Our results demonstrated that force expression VEGI suppressed renal cell carcinoma growth in vivo. Comparing with controls, tumor volume was reduced $>50 \%$ in the group of $\mathrm{BALB} / \mathrm{c}$ nude mice injected with $786-\mathrm{O}^{\text {VEGIexp4 }}$ cells. However, manipulation of VEGI expression had no impact on growth, or apoptosis of RCC cells in vitro. Combined with the result of endothelial cell differentiation assay (tube formation on 
Matrigel), when HUVECs with 786-O ${ }^{\text {VEGIexp4 }}$ were co-cultured, the tube formation decreased significantly in comparison with controls. As indicated by reduced CD31 staining, significant reduction in microvessel density was observed in xenograft tumor samples. All the above suggested that the anti-RCC growth in vivo of force expression VEGI is more likely to be the result of an interference with the development of tumor associated vasculature than that of a direct effect on tumor cells.

The present study also shows that Ki67 and VEGFR2 protein level was decreased significantly in $786-\mathrm{O}^{\text {vEGIexp4 }}$ tumors. It is well known that the $\mathrm{Ki}-67$ protein (also known as MKI67) is a cellular marker for proliferation (43-45). Its high expression may be independently associated with an increased risk of poor disease-free survival for many tumors. Its decrease shows that $786-\mathrm{O}^{\text {VEGIexp4 }}$ cell proliferation was inhibited in vivo. Probably, this kind of inhibition was also dependent on suppressed vasculogenesis. The VEGF/ VEGFR2 pathway plays a central role in tumor vasculature. Blocking it may achieve inhibition of the growth and metastasis of RCC $(46,47)$. VEGFR2 protein level decreased in 786-O ${ }^{\text {VEGIexp4 }}$ tumors indicating that VEGI suppressed angiogenesis through VEGF/VEGFR2 pathway except for DR3, SAPK/JNK and p38 MAPK and caspase pathway $(48,49)$. This is a new pathway of VEGI to suppress angiogenesis not reported before. It is suggested that reducing tumor neovascularisation and tumor cell proliferation rate may be the reason for VEGI suppressing tumor growth in the xenograft model.

In conclusion, the present study shows that VEGI expression is decreased in renal cell carcinoma, particularly in tumors with higher grade. VEGI, a potential cell migration and adhesion regulating protein of TNFSF, suppressed tumor growth in vivo. This is likely via its inhibitory role on antiangiogenesis, cell migration and adhesion. Our results suggest that VEGI may be a putative tumor suppressor and a potential therapeutic target for RCC.

\section{Acknowledgements}

This study was supported by the National Natural Science Foundation of China, grant no. 81072088 and Cancer Research Wales (W.G.J.).

\section{References}

1. Jemal A, Siegel R, Xu J and Ward E: Cancer statistics, 2010. CA Cancer J Clin 60: 277-300, 2010.

2. Bellmunt $\mathbf{J}$ and Guix M: The medical management of metastatic renal cell carcinoma: integrating new guidelines and recommendations. BJU Int 103: 572-577, 2009.

3. Chow WH, Devesa SS, Warren JL and Fraumeni JF Jr: Rising incidence of renal cell cancer in the United States. JAMA 281: 1628-1631, 1999.

4. Ferlay J, Autier P, Boniol M, Heanue M, Colombet M and Boyle P: Estimates of the cancer incidence and mortality in Europe in 2006. Ann Oncol 18: 581-592, 2007.

5. Bechtold RE and Zagoria RJ: Imaging approach to staging of renal cell carcinoma. Urol Clin North Am 24: 507-522, 1997.

6. Kane CJ, Mallin K, Ritchey J, Cooperberg MR and Carroll PR: Renal cell cancer stage migration: analysis of the National Cancer Data Base. Cancer 113: 78-83, 2008.

7. Bellmunt J, Eisen T, Fishman M and Quinn D: Experience with sorafenib and adverse event management. Crit Rev Oncol Hematol 78: 24-32, 2011.
8. Decastro GJ and McKiernan JM: Epidemiology, clinical staging and presentation of renal cell carcinoma. Urol Clin North Am 35: 581-592; vi, 2008.

9. Wallen EM, Pruthi RS, Joyce GF and Wise M: Kidney cancer. J Urol 177: 2006-2018, 2007.

10. Hock LM, Lynch J and Balaji KC: Increasing incidence of all stages of kidney cancer in the last 2 decades in the United States: an analysis of surveillance, epidemiology and end results program data. J Urol 167: 57-60, 2002.

11. Grandinetti CA and Goldspiel BR: Sorafenib and sunitinib: novel targeted therapies for renal cell cancer. Pharmacotherapy 27: 1125-1144, 2007.

12. Motzer RJ and Russo P: Systemic therapy for renal cell carcinoma. J Urol 163: 408-417, 2000.

13. Vakkalanka BK and Rini BI: Targeted therapy in renal cell carcinoma. Curr Opin Urol 18: 481-487, 2008.

14. Fisher RI, Rosenberg SA and Fyfe G: Long-term survival update for high-dose recombinant interleukin-2 in patients with renal cell carcinoma. Cancer J Sci Am 6 (Suppl 1): S55-S57, 2000.

15. Wilhelm SM, Adnane L, Newell P, Villanueva A, Llovet JM and Lynch M: Preclinical overview of sorafenib, a multikinase inhibitor that targets both Raf and VEGF and PDGF receptor tyrosine kinase signaling. Mol Cancer Ther 7: 3129-3140, 2008.

16. Sonpavde G, Choueiri TK, Escudier B, Ficarra V, Hutson TE, Mulders PF, Patard JJ, Rini BI, Staehler M, Sternberg CN and Stief CG: Sequencing of agents for metastatic renal cell carcinoma: can we customize therapy? Eur Urol 61: 307-316, 2012.

17. Porta C, Szczylik C and Escudier B: Combination or sequencing strategies to improve the outcome of metastatic renal cell carcinoma patients: a critical review. Crit Rev Oncol Hematol 82: 323-337, 2012.

18. Paez-Ribes M, Allen E, Hudock J, Takeda T, Okuyama H, Vinals F, Inoue M, Bergers G, Hanahan D and Casanovas O: Antiangiogenic therapy elicits malignant progression of tumors to increased local invasion and distant metastasis. Cancer Cell 15: 220-231, 2009.

19. Huang D, Ding Y, Zhou M, Rini BI, Petillo D, Qian CN, Kahnoski R, Futreal PA, Furge KA and Teh BT: Interleukin-8 mediates resistance to antiangiogenic agent sunitinib in renal cell carcinoma. Cancer Res 70: 1063-1071, 2010.

20. Finke J, Ko J, Rini B, Rayman P, Ireland J and Cohen P: MDSC as a mechanism of tumor escape from sunitinib mediated antiangiogenic therapy. Int Immunopharmacol 11: 856-861, 2011.

21. Tan KB, Harrop J, Reddy M, Young P, Terrett J, Emery J, Moore G and Truneh A: Characterization of a novel TNF-like ligand and recently described TNF ligand and TNF receptor superfamily genes and their constitutive and inducible expression in hematopoietic and non-hematopoietic cells. Gene 204: 35-46, 1997.

22. Zhai Y, Yu J, Iruela-Arispe L, Huang WQ, Wang Z, Hayes AJ, Lu J, Jiang G, Rojas L, Lippman ME, Ni J, Yu GL and Li LY: Inhibition of angiogenesis and breast cancer xenograft tumor growth by VEGI, a novel cytokine of the TNF superfamily. Int J Cancer 82: 131-136, 1999.

23. Zhai Y, Ni J, Jiang GW, Lu J, Xing L, Lincoln C, Carter KC, Janat F, Kozak D, Xu S, Rojas L, Aggarwal BB, Ruben S, Li LY, Gentz R and Yu GL: VEGI, a novel cytokine of the tumor necrosis factor family, is an angiogenesis inhibitor that suppresses the growth of colon carcinomas in vivo. FASEB J 13: 181-189, 1999.

24. Chew LJ, Pan H, Yu J, Tian S, Huang WQ, Zhang JY, Pang S and Li LY: A novel secreted splice variant of vascular endothelial cell growth inhibitor. FASEB J 16: 742-744, 2002.

25. Yue TL, Ni J, Romanic AM, Gu JL, Keller P, Wang C, Kumar S, Yu GL, Hart TK, Wang X, Xia Z, DeWolf WE Jr and Feuerstein GZ: TL1, a novel tumor necrosis factor-like cytokine, induces apoptosis in endothelial cells. Involvement of activation of stress protein kinases (stress-activated protein kinase and p38 mitogen-activated protein kinase) and caspase-3-like protease. J Biol Chem 274: 1479-1486, 1999.

26. Zhang N, Sanders AJ, Ye L, Kynaston HG and Jiang WG: Expression of vascular endothelial growth inhibitor (VEGI) in human urothelial cancer of the bladder and its effects on the adhesion and migration of bladder cancer cells in vitro. Anticancer Res 30: 87-95, 2010.

27. Zhang N, Sanders AJ, Ye L, Kynaston HG and Jiang WG: Vascular endothelial growth inhibitor, expression in human prostate cancer tissue and the impact on adhesion and migration of prostate cancer cells in vitro. Int J Oncol 35: 1473-1480, 2009. 
28. Xiao Q,Hsu CY, Chen H, Ma X, Xu J and Lee JM: Characterization of cis-regulatory elements of the vascular endothelial growth inhibitor gene promoter. Biochem J 388: 913-920, 2005.

29. Hou W, Medynski D, Wu S, Lin X and Li LY: VEGI-192, a new isoform of TNFSF15, specifically eliminates tumor vascular endothelial cells and suppresses tumor growth. Clin Cancer Res 11: 5595-5602, 2005.

30. Yao JJ, Zhang M, Miao XH, Zhao P, Zhu SY, Ding H and Qi ZT: Isoform of vascular endothelial cell growth inhibitor (VEGI72-251) increases interleukin-2 production by activation of T lymphocytes. Acta Biochim Biophys Sin (Shanghai) 38: 249-253, 2006

31. Jin T, Kim S, Guo F, Howard A and Zhang YZ: Purification and crystallization of recombinant human TNF-like ligand TL1A. Cytokine 40: 115-122, 2007.

32. Park SS, Lillehoj HS, Hong YH and Lee SH: Functional characterization of tumor necrosis factor superfamily 15 (TNFSF15) induced by lipopolysaccharides and Eimeria infection. Dev Comp Immunol 31: 934-944, 2007.

33. Cai J, Jiang WG and Mansel RE: Inhibition of the expression of VE-cadherin/catenin complex by gamma linolenic acid in human vascular endothelial cells and its impact on angiogenesis. Biochem Biophys Res Commun 258: 113-118, 1999.

34. Zhang N, Sanders AJ, Ye L and Jiang WG: Vascular endothelial growth inhibitor in human cancer (Review). Int J Mol Med 24: 3-8, 2009.

35. Migone TS, Zhang J, Luo X, Zhuang L, Chen C, Hu B, Hong JS, Perry JW, Chen SF, Zhou JX, Cho YH, Ullrich S, Kanakaraj P, Carrell J, Boyd E, Olsen HS, Hu G, Pukac L, Liu D, Ni J, Kim S, Gentz R, Feng P, Moore PA, Ruben SM and Wei P: TL1A is a TNF-like ligand for DR3 and TR6/DcR3 and functions as a T cell costimulator. Immunity 16: 479-492, 2002.

36. Bamias G, Mishina M, Nyce M, Ross WG, Kollias G, RiveraNieves J, Pizarro TT and Cominelli F: Role of TL1A and its receptor DR3 in two models of chronic murine ileitis. Proc Nat Acad Sci USA 103: 8441-8446, 2006.

37. Prehn JL, Thomas LS, Landers CJ, Yu QT, Michelsen KS and Targan SR: The T cell costimulator TL1A is induced by FcgammaR signaling in human monocytes and dendritic cells. J Immunol 178: 4033-4038, 2007.

38. Parr C, Gan $\mathrm{CH}$, Watkins $\mathrm{G}$ and Jiang WG: Reduced vascular endothelial growth inhibitor (VEGI) expression is associated with poor prognosis in breast cancer patients. Angiogenesis 9: 73-81, 2006
39. Chen X, Wu J, Liu H, He Z, Gu M, Wang N, Ma J, Hu J, Xia L, He H, Yuan J, Li J, Li L, Li M and Zhu X: Approaches to efficient production of recombinant angiogenesis inhibitor rhVEGI-192 and characterization of its structure and antiangiogenic function. Protein Sci 19: 449-457, 2010.

40. Liang PH, Tian F, Lu Y, Duan B, Stolz DB and Li LY: Vascular endothelial growth inhibitor (VEGI; TNFSF15) inhibits bone marrow-derived endothelial progenitor cell incorporation into Lewis lung carcinoma tumors. Angiogenesis 14: 61-68, 2011.

41. Haridas V, Shrivastava A, Su J, Yu GL, Ni J, Liu D, Chen SF, Ni Y, Ruben SM, Gentz R and Aggarwal BB: VEGI, a new member of the TNF family activates nuclear factor-kappa B and c-Jun N-terminal kinase and modulates cell growth. Oncogene 18: 6496-6504, 1999.

42. McGuire BB and Fitzpatrick JM: Biomarkers in renal cell carcinoma. Curr Opin Urol 19: 441-446, 2009.

43. Li XQ, Pei DS, Qian GW, Yin XX, Cheng Q, Li LT, Li HZ and Zheng JN: The effect of methylated oligonucleotide targeting Ki-67 gene in human 786-0 renal carcinoma cells. Tumour Biol 32: $863-872,2011$

44. Oka S, Uramoto H, Shimokawa H, Iwanami T and Tanaka F: The expression of $\mathrm{Ki}-67$, but not proliferating cell nuclear antigen, predicts poor disease free survival in patients with adenocarcinoma of the lung. Anticancer Res 31: 4277-4282, 2011

45. Carmeliet P: VEGF as a key mediator of angiogenesis in cancer. Oncology 69 (Suppl 3): 4-10, 2005.

46. Hicklin DJ and Ellis LM: Role of the vascular endothelial growth factor pathway in tumor growth and angiogenesis. J Clin Oncol 23: 1011-1027, 2005.

47. Yang CR, Hsieh SL, Teng CM, Ho FM, Su WL and Lin WW Soluble decoy receptor 3 induces angiogenesis by neutralization of TL1A, a cytokine belonging to tumor necrosis factor superfamily and exhibiting angiostatic action. Cancer Res 64: 1122-1129, 2004.

48. Cassatella MA, Pereira-da-Silva G, Tinazzi I, Facchetti F, Scapini P, Calzetti F, Tamassia N, Wei P, Nardelli B, Roschke V, Vecchi A, Mantovani A, Bambara LM, Edwards SW and Carletto A: Soluble TNF-like cytokine (TL1A) production by immune complexes stimulated monocytes in rheumatoid arthritis. J Immunol 178: 7325-7333, 2007. 